\title{
TOWARDS A TRAINER PROFILE ON GREEN SKILLS FOR PORTUGAL: BUS.TRAINERS PROJECT
}

\author{
A.P. Duarte ${ }^{1}$, D. Loureiro ${ }^{1}$, A. Gonçalves ${ }^{1}$, E. Reis ${ }^{2}$, M. Ramalheiro ${ }^{2}$, J. Santos ${ }^{2}$, \\ B. Oliete ${ }^{3}$, J. Gonzalez ${ }^{3}$ \\ ${ }^{1}$ LNEG - Laboratório Nacional de Energia e Geologia (PORTUGAL) \\ ${ }^{2}$ CENFIC -Centro de Formação Profissional da Indústria da Construção Civil e Obras \\ Públicas do Sul (PORTUGAL) \\ ${ }^{3}$ FLC - Fundación Laboral de la Construcción (SPAIN)
}

\begin{abstract}
Green skills in the construction industry will fill in a very important role for the adaptation strategy to climate change and in development of more energy-efficient economies and employment growth to make EU states more climate-resilient. To get the most out of greening the economy vocational education research must develop the skills, knowledge and competence that resource-efficient processes and technologies need and integrate them into policy and the practices of business and the community. In order to respond the transition challenge to green economy BuS.Trainers project was drawn financed by ERASMUS ${ }^{+}$program included in the Sector Skills Alliances for Design and Delivery of VET (Vocational Education and Training), because there was a central need along southern countries of Europe: lack of qualified VET trainers for teaching green skills in the construction industry. The project aims to identify and filling gaps of Green Skills for the trainers, who are providing training on EE (Efficiency Energy) and RES (Renewable Energy Sources) in construction industry through development and offer a training system for vocational trainers to perform better teaching in applied sustainable construction. In this article the strategy and results of the project in terms of construction trainer profile on green skills for Portugal are presented. It includes the results of an online survey and semi-structured interviews filled by VET trainers and other specialists for identification and definition of existing Green Skills Gaps. The project is coordinated by Fundación Laboral de la Construcción (FLC - Spain) and five European countries are involved: Spain, Greece, Italy, Malta and Portugal. This European project has duration of 3 years and started in December 2016.
\end{abstract}

Keywords: Vocational Education and Training, Green Skills, Construction Industry, Sustainable Construction.

\section{INTRODUCTION}

The construction and use of buildings in EU is responsible for about half of all extracted materials and energy consumption, about a third of the water consumption and also about one third of all wastes [1, 2,3 , and 4]. Thus, it is expected that the construction sector through legislation, benchmarking, best practices, new technologies, new materials, training and new behaviours, among others, would contribute to meet the European 2020 energy objectives [5] and also the new climate and energy objectives for 2030 [6] and 2050 [7].

Energy efficiency will be fundamental beyond 2020 [5], and the 2030 framework aims to make the European Union's economy and energy system more competitive, secure and sustainable [6]. Together, these goals provide the EU with a steady policy framework on greenhouse gas emissions, renewables and energy efficiency.

But in order to meet these objectives major efforts are required to improve the overall skills of building workers, and within these, specifically the Green Skills, which are considered key to reduction of climate change, development of more energy-efficient economies in terms of resources and growth of employment [8].

In this article we adopted the definition of Green Skills of the European Centre for the Development of Vocational Training (CEDEFOP) in 2012 [8, 9]: "the knowledge, abilities, values and attitudes needed to live in, develop and support a sustainable and resource-efficient society". These skills "will be needed by all sectors and at all levels in the workforce" and the greening of the economy "requires upgrading skills and adjusting qualification requirements" [8]. 